\title{
Üstün Yetenekli Öğrenciler ile Akranlarının Sayı Hissi Alt Bileşenlerinin Karşılaştırılması ${ }^{1}$ *
}

\author{
Adem DOĞAN \\ Dr. Öğr. Üyesi, Kahramanmaraş Sütçü İmam Üniversitesi, \\ Eğitim Fakültesi, Temel Eğitim Bölümü \\ aademdogan@gmail.com \\ Orcid ID: https://orcid.org/0000-0001-6952-7415
}

\section{Seyhan PAYDAR}

Hacettepe Üniversitesi, Sosyal Bilimler Enstitüsü, Doktora Öğrencisi spaydar@hacettepe.edu.tr

Orcid ID: https://orcid.org/0000-0001-5165-2509

\begin{abstract}
Öz
Öğrencilerde sayı hissi, mantıksal çıkarım yapmasını kolaylaştıran bir düşünme biçimi geliştirmesine olanak sağlamaktadır. Matematik Öğretmenleri Ulusal Konseyi (NCTM, 2000), sayı ve işlemlerin anlaşılması, sayı hissi gelişimi ve aritmetik işlemlerde akıcıllğın kazanılmasını sağlamak amacıyla, "Tüm öğrenciler sayı hissini ve sayıları farklı durumlarda kullanabilme ve sayıları farklı formlarda temsil etme becerisini geliştirmelidir.” tavsiyesinde bulunmuştur. Başarılı matematik kullanıcılarının bir özelliği olarak da benimsenen sayı hissi ile bu kavramın alt bileşenlerinin, ülkemizde üstün yetenekli tanısı konan ve Bilim ve Sanat Merkezlerinde öğrenim görmekte olan öğrenciler ile tanı konulmayan öğrenciler arasındaki ilişki düzeylerinin incelenmesi amacıyla yapılmış betimsel bir çalışmadır. Çalışma 182 üstün yetenekli tanısı konan, 122 de üstün yetenekli tanısı konmayan 4. ve 5.sınıf öğrencisi ile yapılmıştır. Veri toplama arac1 olarak Reys, Reys, Emanuelsson, Johansson, McIntosh ve Yang (1999)'ın belirlediği sayı hissi alt bileşenlerine göre araştırmacılar tarafından geliştirilen 17 soruluk bir başarı testi kullanılmıştır. Çalışma sonucunda farklı
\end{abstract}

\footnotetext{
${ }^{1}$ Makale Geliş/Kabul Tarihi: 14.02.2020 / 08.04.2020

*Üstün yetenekli öğrenciler için olan verilerin bir kısmı 18. Uluslararası Sınıf Öğretmenliği Eğitimi Sempozyumu'nda (USOS 2019); 4. ve 5. sinıf öğrencilerine yönelik verilerin bir kısmı ise 28. Uluslararası Eğitim Bilimleri Kongresi'nde (ICES/UEBK-2019) sözlü bildiri olarak sunulmuştur.

Künye Bilgisi: Doğan, A. ve Paydar, S. (2020). Üstün Yetenekli Öğrenciler ile Akranlarının Sayı Hissi Alt Bileşenlerinin Karşılaştırılması. Kahramanmaraş Sütçü Imam Üniversitesi Sosyal Bilimler Dergisi, 17 (1), 21-44. DOI: 10.33437/ksusbd.689146
} 
sayı hissi bileşenlerinde hem sınıf seviyesine göre hem de üstün yetenekli tanısı konan ve konmayan öğrenciler arasında çeşitli farklılıklar çıkmıştır.

Anahtar Kelimeler: Sayı Hissi, Sayı Hissi Alt Bileşenleri, Üstün Yetenekli Öğrenciler, 4. ve 5. sinıf.

\title{
Comparing Gifted Students and Their Peers' Sub-Components of Number Sense
}

\begin{abstract}
The sense of number in students enables it to develop a way of thinking that facilitates logical inference. Principles and Standards for School Mathematics (NCTM 2000) recommend that all students should develop their sense of number and ability to use numbers in different situations and to represent numbers in different forms for understanding numbers and transactions, development of number sense and ensuring fluency in arithmetic operations. This descriptive study was motivated to compare 4th and 5th grade students and their gifted peers regarding development of number sense and sub-components of number sense that are counted among characteristics of successful users of mathematics. Participants of the research were 122 4th and 5th graders and 182 gifted students attending the same classes at a Centre of Science and Arts in Turkey. Data were collected through a 17-item performance test developed by the researchers based on sub-components of number sense (Reys, Reys, Emanuelsson, Johansson, McIntosh ve Yang 1999). The results indicated significant differences in the development of sub-components of number sense in students with respect to the attended grade and giftedness.
\end{abstract}

Keywords: Number Sense, Sub-Components Of Number Sense, Gifted Students, 4th and 5th Grade.

\section{GİRIŞ}

Asırlar boyunca çeşitli eğitim kademelerinde zorunlu ders olarak okutulan matematik, eski bir bilim dalı olmasının yanı sıra sosyal seçimin önemli bir ölçütü ve tüm eğitim sistemlerinin vazgeçilmez parçası olagelmiştir (Oliveira, Negreiros ve Neves, 2015). Yaşamın tüm yönlerini kapsıyor olması sebebiyle öğrenciler ve hayatın diğer tüm kesimlerindeki bireyler, günlük işlerini etkili bir şekilde gerçekleştirmeleri, toplumun üretken, işlevsel ve bağımsız fertleri olmaları konusunda matematik eğitimi göz ardı edilemez bir öneme sahiptir (Etuk ve 
Bello, 2016). Ülkemizde, 1739 sayılı Millî Eğitim Temel Kanunu'nda belirlenmiş olan genel amaçlar ve temel ilkeler doğrultusunda 2018 yllında güncellenen Matematik Dersi Öğretim Programında "matematiksel okuryazarlık becerilerinin geliştirilmesi ve etkin bir şekilde kullanımı", "matematiksel kavramların anlaşılması ve günlük hayatta kullanımı", "problem çözme sürecinde akıl yürütme", "matematiksel düşüncelerin mantık çerçevesinde açıklanması", "matematiğin anlam ve dilinin kullanılarak insan ile nesneler arasındaki ilişkiler ile nesneler arasındaki ilişkilerin anlamlandırılması", "üst-bilişsel bilgi ve becerilerin geliştirilmesi", "tahmin yürütme ve zihinden işlem yapma becerilerinin etkin bir şekilde kullanılması", "kavramların farklı temsil biçimleri ile ifade edilmesi" ve "araştırma yapma, bilgi üretme ve kullanma becerilerinin geliştirilmesi" gibi amaçlara değinilmiştir (MEB, 2018). Ancak, tüm bilim dallarında olduğu gibi matematik bilimine/ dersine yatkınlık konusunda da bireysel farklılıklara rastlanmaktadır. Bu farklılığın temel sebeplerinden birinin "sayı hissi" kavramı ile ilgili olduğu ifade edilmektedir (Mutlu, Olkun ve Cumhur, 2019; NCTM, 2000; Olkun ve Toluk-Uçar, 2009; Olkun, Altun, Şahin ve Denizli, 2015; Yang ve Li, 2013). Sayı hissi kavramı, sayıların esnek kullanımı, sayısal işlemlerde pratik düşünme, en etkili ve işlevsel çözüm yolunu seçme, bazı durumlarda duruma pek de uygun olmayan standart dışı yöntemlerin bulunmas1/ üretilmesi, problemlerin karşılaştırma yöntemi ile kolaylaştırılması ve kavramsal düşünme ile kesirlerin farklı gösterimi olarak tanımlanmaktadır (Altay, 2010). Matematiğe yatkınlık konusunda önemli bir yere sahip olan bu kavramın, matematik algısı ya da genel algılama yetisi ile yakından ilgili olduğu düşünülmektedir. İnsan beyninde, öğrenmenin gerçekleşmesi, kavramlar arasında bağın kurulması ve sürdürülmesini sağlayan yapılar mevcuttur. Söz konusu ilişki ağlarının oluşumunda gözlemlenen bireysel farklılara istinaden, sayı hissi ve alt bileşenleri bazı bireylerde farklı gelişebilmektedir.

Amerika Birleşik Devletleri'nde matematik eğitimi konusundaki ilke ve standartların belirlenmesinden sorumlu Matematik Öğretmenleri Ulusal Konseyi (NCTM, 2000) tarafindan, sayı ve işlemlerin anlaşılması, sayı hissi gelişimi ve aritmetik işlemlerde akıcılığın kazanılmasını sağlamak amacıyla, "Tüm ögrenciler sayı hissini ve sayıları farkl durumlarda kullanabilme ve sayılar farkl formlarda temsil etme becerisini gelişstirecektir" ifadesi kullanılmıştır. Başarılı matematik kullanıcılarının bir özelliği olarak da benimsenen sayı hissi ile bu kavrama ait alt bileşenlerin, ülkemizde Bilim ve Sanat Merkezlerinde (BİLSEM) öğrenim görmekte olan üstün yetenekli öğrencilerde oluşum düzeylerinin incelenmesi, bu çalışmanın genel amacını teşkil etmektedir. $\mathrm{Bu}$ öğrencilerin gelişmiş akademik fursatlar sağlanması halinde, yenilikçilik ve ekonomik büyümeye öncülük edecek (Nobbe ve Davis, 2019), tıp, bilim, siyaset, iş ve sanat dünyasında adından söz ettirecek kapasitede olduğu öne sürülmektedir (Fisher, 2013). Ayrıca, teknolojide meydana gelen birçok yeniliğin üstün yetenekli bireylerin kapasitelerini kullanmaları sonucunda ortaya çıktığı ifade 
edilmektedir (Clinkenbeard, 2007; Florida, 2005; Rindermann, Sailer ve Thompson, 2009).

Renzulli (1986) üstün yetenekli çocukların, ortalamanın üstünde zekâya sahip olma, yaratıcılık ve görev bağlılığı olmak üzere üç temel alanda öne çıkmalarının beklendiğini belirtmektedir. Bu üç alanın etkileşimi sonucunda, üstün yetenekli bireylerin kendilerini matematik, felsefe, din veya görsel sanatlar gibi genel performans alanlarında kanıtlayabileceği vurgulanmaktadır. Üstün yetenekliler, "zekâ, yaratıcılık, sanat, liderlik kapasitesi veya özel akademik alanlarda yaşıtlarına göre yüksek düzeyde performans gösterdiği uzmanlar tarafından belirlenen bireyler" şeklinde de tanımlanmaktadır (MEB, 2016). Üstün yetenekli öğrencilerin, matematik alanında diğer öğrencilerden daha farklı becerilere sahip olması ve buna istinaden sayı hissi bakımından daha gelişmiş olmaları beklenmektedir. $\mathrm{Bu}$ bağlamda, yukarıda sözü edilen BİLSEM'lerde üstün yetenekli öğrencilere yönelik uygulanan zenginleştirilmiş eğitim programının bu öğrencilerin sayı hissi oluşum düzeylerine etkisinin ölçülmesi, çalışmanın sonuçları bakımından önem arz etmektedir.

Günlük hayatımızın her alanında sayıları kullanarak birtakım işlemler yaparız. Sayılarla yapılan bu işlemler dizisini öğrenilen kurallar yerine daha kolay ve farklı çözüm yolları ile gerçekleştirmemiz mümkündür. Başka bir deyişle, sayılara ilişkin kural kullanımı ile işlem yapmak yerine çeşitli stratejiler ile sayı hissi olarak adlandırdığımız bilgimizi kullanabiliriz. Sayı hissi "en temel anlamda çevrenin sayısal yönleri için bireyin sezgisel hissiyatını ifade eder” (Westwood, 2000, 27). Kurallı işlemler dizisinden bizi farklı bir yöne taşıyan sayı hissi, zihinde ilk 20 sayının ilişkilendirilmesi ile başlar. Sayı hissi süreci küçük sayılar ile sona ermeyip daha büyük sayılar ile tanıştıkça, basamak değeri kavramı ile hesaplamalar yapmada, kesirler, ondalık sayı ve yüzdelik sayılar ile yapılan hesaplamalarda devam eder (Van de Walle, Karp, Bay-Wiliams, 2012).

Sayı hissi oluşumunun yapılan araştırmalar sonucunda tespit edilen faydaları şunlardır: i) Öğrencilerin mantıksal çıkarım yapmasını kolaylaştıran bir düşünme biçimi geliştirmesine olanak sağlar. ii) Öğrencilerin matematik başarısının artmasında etkili rol oynar. iii) Anlamlı öğrenme sürecini teşvik ederek yazılı hesaplamalar yerine zihinden işlemlerle öğrencilerin matematiksel düşünme ve anlayışını geliştirir. iv) Öğrencilerin problemleri esnek yöntemler kullanarak çözmesi ve kavramsal anlayışının gelişmesine katkı sağlar (Dunphy, 2007; Markovits ve Sowder, 1994; Yang ve Li, 2013).

Uzun bir süreç gerektiren sayı hissi kavramının oluşumu, matematik öğretiminin farklı aşamalara taşınması ve öğretim sürecine farklı bir bakış açısı getirilmesi açısından araştırılması önem arz eden bir konudur. Sayı hissi ile ilgili ülkemizde yapılan çalışmalar, öğrencilerin sayı hissi yerine kurala dayalı, rutin 
işlemler ile soruları yanıtladıklarını ortaya koymaktadır (Çekirdekçi, Şengül ve Doğan, 2016; Dede, 2015; Gülbağcı-Dede ve Şengül, 2016; İymen ve Paksu, 2015; Kartal, 2016; Kayhan-Altay, 2010; Kayhan-Altay ve Umay, 2011; Şengül ve Gülbağcı-Dede, 2014). Yurt dışında yapılan çalışmalarda ise, sayı hissinden çok kurallara dayalı işleme yapıldığı, sayı hissinin öğretimle geliştirilebileceği ve sayı duyusu ile matematik başarısı arasındaki ilişkiye değinildiği gözlemlenmiştir (Armeria-Zavala ve Hernandez-Gallardo, 2012; Jordan, Kaplan, Locuniak ve Ramineni, 2007; Reys, Reys, Emanuelsson, Johansson, McIntosh ve Yang, 1999; Vapumarican ve Kapur, 2012; Yang, Li ve Lin, 2008).

İnsan hayatında bir süreç ifade eden sayı hissi, farklı araştırmacılar tarafından birtakım sınıflandırmalar ile açıklanmıştır (Greeno, 1991; Markovits ve Sowder, 1994; McIntosh, Reys ve Reys, 1992; Reys, vd., 1999; Sowder ve Schappelle, 1994). İsveç, ABD, Avustralya ve Tayvan'da 8-14 yaş grubunda olan öğrenciler üzerinde sayı hissi bileşenlerini konu alan araştırmalarında, Reys vd., (1999), öğrencilerin sayı hissi yeterliliklerini ölçerek bir sınıflama ortaya koymuştur. Bunlar: (i) Sayının anlamının ve büyüklüğünü anlama, (ii) sayının eş gösterimlerini anlama ve kullanma, (iii) işlemlerin anlamını ve etkisini anlama, (iv) eş ifadelerin kullanımı ve anlamı, (v) zihinden işlem, yazılı işlem ve hesap makinesi kullanımı için sayma ve esnek işlem stratejileri, (vi) ölçüm referanslarıdır.

Sayı hissi konusunda yapılan çalışmaların öğrenci ve öğretmenlerin sayı hissinden çok öğretilen birtakım kuralları kullandığı, sayı hissinin öğretilebilir olması ve sayı hissinin matematik başarısını etkilemesi gibi sonuçlarından hareketle, bu çalışmada, öğrencilerin sayı hissi konusunda başarılı olduğu ve güçlük yaşadığı aşamaların belirlenmesi ile dördüncü ve beşinci sınıf öğrencilerinin sayı hissi düzeylerinin karşılaştııılması amaçlanmıştır. $\mathrm{Bu}$ doğrultuda, dördüncü ve beşinci sınıf öğrencilerinin sayı hissi düzeyleri, Reys vd., (1999) tarafından geliştirilen 6 bileşene göre açıklanmaya çalışılmıştır.

Günlük hayatımızın her alanında sayıları kullanır ve sayılar ile birtakım işlemler yaparız. Sayılarla yapılan bu işlemler dizisini öğrenilen kurallar yerine daha kolay yollardan ve farklı çözüm yolları ile hesaplamamız mümkündür. Sayılarla kural kullanarak işlem yapmak yerine çeşitli stratejiler ile sayı hissi olarak adlandırdığımız bilgimizi kullanabiliriz. Sayı hissi "en temel anlamda çevrenin sayısal yönleri için bireyin sezgisel hissiyatını ifade eder" (Westwood, 2000, 27). Kurallı işlemler dizisinden bizi farklı bir yöne taşıyan sayı hissi ilk 20 sayıdaki ilişkilendirmeler ile başlar. Sayı hissi süreci küçük sayılar ile sona ermeyip daha büyük sayılar ile tanıştıkça, basamak değeri kavramı ile, hesaplamalar yapmada, kesirler, ondalık sayı ve yüzdelik sayılar ile yapılan hesaplamalarda devam eder (Wan de Walle, Karp, Bay-Wiiliams, 2016). 
Uzun bir süreci içeren sayı hissi kavramı matematik öğretimini farklı aşamalara taşımak için ve öğretim sürecine farklı bir bakış açısı getirmek adına araştırılması önem arz eden bir konudur. Sayı hissi ile ilgili ülkemizde yapılan çalışmalar (Çekirdekçi, Şengül ve Doğan, 2016; Altay, 2011; İymen ve Paksu, 2015; Dede, 2015; Kartal, 2016) öğrencilerin sayı hissi yerine kurala dayalı, rutin işlemler ile soruları yanıtladıklarını ortaya koymaktadır. Yurt dışında yapılan çalışmalarda (Reys, Reys, Emanuelsson, Johansson, McIntosh ve Yang, 1999; Yang, Li ve Lin, 2008; Jordan, Kaplan, Locuniak ve Ramineni, 2007; (ArmeriaZavala ve Hernandez-Gallardo, 2012; Vapumarican ve Kapur, 2012) say1 hissinden çok kurallara dayalı işleme yapıldığı, sayı hissinin öğretimle geliştirilebileceğine ve sayı duyusu ile matematik başarısı arasındaki ilişkiye değinen çalışmalar mevcuttur.

Sayı hissi ile ilgili yapılan çalışmalar göz önüne alındığında öğrencilerin ve öğretmenlerin sayı hissinden daha çok öğretilen birtakım kurallar kullandığı, sayı hissinin öğretilebilir olması ve sayı hissinin matematik başarısını etkilemesi sonuçlarından hareketle bu çalışmada öğrencilerin sayı hissi konusunda hangi aşamada güçlük yaşadığını ve hangi aşamada başarılı olduklarını ortaya koymak oldukça önemlidir. Bunun için ilkokulun sonu olan dördüncü sınıf ile ortaokulun başlangıcı olan beşinci sınıf öğrencilerinin sayı hissi durumlarını karşılaştırmak amaçlanmıştır. Bu amaçla Reys ve arkadaşlarının (1999) sayı hissini ölçen 6 bileşene göre (sayının anlamının ve büyüklüğünü anlama, sayının eş gösterimlerini anlama ve kullanma, işlemlerin anlamını ve etkisini anlama, eş ifadelerin kullanımı ve anlamı, zihinden işlem, yazılı işlem ve hesap makinesi kullanımı için sayma ve esnek işlem stratejileri, ölçüm referansları) durumları ortaya çıkarılmaya çalışılmıştır.

Alt Problemler:

1) Devlet okuluna devem eden dördüncü ve beşinci sınıf öğrencilerinin sayma ilkelerine ulaşma düzeyleri nedir?

2) BİLSEM'e devem eden BYF öğrencilerinin sayma ilkelerine ulaşma düzeyleri nedir?

3) Devlet okuluna devam eden dördüncü ve beşinci sınıf öğrencilerinin sayı hissinin her bir alt bileşenlerine göre alınan puanlar arasında anlamlı fark var midır?

4) BILLSEM'e devam eden BYF sınıf öğrencilerinin sayı hissinin her bir alt bileşenlerine göre alınan puanlar arasında anlamlı fark var mıdır? 


\section{YÖNTEM}

\section{Araștırma Modeli}

$\mathrm{Bu}$ çalışma birinci ve ikinci alt problem kapsamında BILSEM'e ve devlet okuluna devam eden dördüncü ve beşinci sınıf öğrencilerinin sayı hissi ilkelerinde istenilen öğrenme düzeyine ulaşması yönüyle betimsel bir çalışmadır. Betimsel araştırmalar mevcut durumu dikkatli ve tam olarak ifade eder (Fraenkel, Wallen ve Hyun, 2012). Üçüncü, dördüncü, beşinci ve altınc1 alt problem kapsamında öğrencilerin devam ettikleri eğitim merkezi ve sınıf düzeyi değişkenlerinin öğrencilerin sayı hissi başarısına etkisi herhangi bir müdahale yapılmaksızın belirlenmeye çalışılması yönüyle ise nedensel karşılaştırma çalışmasıdır. Nedensel karşıllaştırma araştırmaları herhangi bir müdahale olmaksızın insan gruplarındaki farklılıkların neden ve sonuçlarını ortaya koymaya çalışan araştırmalardır (Büyüköztürk, Çakmak, Akgün, Karadeniz ve Demirel, 2011).

\section{Çalışma Grubu}

Araştırmanın çalışma grubunu 2018-2019 eğitim öğretim Ankara'nın Haymana ve Keçiören ilçe merkezlerinde bulunan devlet okuluna devam eden dördüncü sınıf 60 öğrenci ve beşinci sınıf 62 öğrenci oluşturmaktadır. Üstün yetenekli öğrenciler ise Ankara, Mersin ve Kahramanmaraş illerinde BİLSEM'e devam eden 96 dördüncü ve 86 beşinci sınıf BYF programı öğrencisinden oluşmaktadır. Bunun için ilkokulun sonu olan dördüncü sınıf ile ortaokulun başlangıcı olan beşinci sınıf öğrencilerinin sayı hissi durumlarını karşılaştırmak amaçlanmıştır. BİLSEM öğrencileri 4. ve 5. sınıf seviyesinde bireysel yetenekleri fark ettirme programı (BYF) eğitim sürecindedir. Bireysel yetenekleri fark ettirme programı (BYF), zihinsel yetenek alanından tanılanan ve destek eğitim programını tamamlayan öğrencilerin bireysel yeteneklerini fark etmeleri amacıyla yürütülen eğitim programıdır (MEB, 2016). Bu kapsamda araştırmaya 304 öğrenci katılmıştır. Üstün yetenekli öğrencilerin farklı illerden seçilmesinin nedeni ise aynı ilde çalışmayı destekleyecek sayıda gönüllü BYF dönemi öğrencisinin bulunmamasından kaynaklanmıştır. Araştırmanın çalışma grubu oluşturulurken amaçlı örneklemeden ölçüt örnekleme türü kullanılmıştır. Çalışmanın ölçütlerini öğrencilerin dördüncü ve beşinci sınıfa gitme ile BILLSEM ile devlet okuluna devam etme durumları ölçüt olarak alınmıştır. Ölçüt örnekleme çalışması bir dizi ölçütü karşılayan bütün durumların çalışılmasıdır (Yıldırım ve Şimşek, 2016). Bu çalışmada ölçüt olarak devlet okulundaki öğrenciler için 4. ve 5. sinıf öğrencisi olmak; üstün yetenekli öğrenciler için ise 4. ve 5. sınıf öğrencisi olup BİLSEM'de öğrenim gören BYF dönemi öğrencisi olma durumu belirlenmiştir. 


\section{Veri Toplama Aracı}

Dördüncü ve beşinci sınıf öğrencilerinin sayı hissini ölçmeyi amaçlayan bu çalışmada veri toplama aracı hazırlanırken Reys ve arkadaşlarının (1999) belirlediği sayı hissi bileşenleri olan sayının anlamının ve büyüklügünü anlama, sayının eş gösterimlerini anlama ve kullanma, işlemlerin anlamını ve etkisini anlama, eş ifadelerin kullanımı ve anlamı, zihinden işlem, yazılı işlem ve hesap makinesi kullanımı için sayma ve esnek işlem stratejileri, ölçüm referansları ilkelerine göre 17 sorudan oluşan test araştırmacılar tarafından ilkokul matematik dersi öğretim programındaki dördüncü ve beşinci sınıf kazanımlarına uygun olarak hazırlanmıştır. Soruların anlaşılırlığını kontrol etmek amacıyla pilot uygulama yapılmış ve bir sorunla karşılaşılmamıştır. Testin güvenilirliği KR-20 70,3 olarak hesaplanmıştır.

\section{Veri Toplama ve Analizi}

Araştırmanın veri toplama aşamasında araştırmacılar tarafindan geliştirilen "Sayı Hissi Testi” (SHT) kullanılmıştır. Ankara'nın Haymana ve Keçiören ilçe merkezlerinde 4. ve 5. sınıfına devam eden öğrenciler ile Ankara, Mersin ve Kahramanmaraş illerinde bulunan üç BILLSEM'deki BYF öğrencilerinden veri toplanmiştır.

Testin analiz aşamasında sorulara verilen yanlış cevaplara 0 , standart olarak verilen doğru cevaplara 1 , sayı hissi becerisi olduğu halde yanlış cevap verilen sorulara 2, sayı hissi becerisi ile doğru yapılan sorulara 3 puan verilerek cevaplar kodlanmıştır. Birinci ve ikinci alt problemlerin analizi için devlet okulunda ve BİLSEM'de eğitim gören 4. ve 5. sınıf öğrencilerinin sayı hissi bileşenleri olan sayının anlamını ve büyüklüğünü anlama, sayının eş gösterimlerini anlama ve kullanma, işlemlerin anlamını ve etkisini anlama, eş ifadelerin kullanımı ve anlamı, zihinden işlem, yazılı işlem ve hesap makinesi kullanımı için sayma ve esnek işlem stratejileri, ölçüm referansları ilkelerinin her birine ulaşma düzeyleri belirlenmiştir. Sayı hissinin her bir ilkesi için öğrencilerin becerilerde başarılı kabul edilme düzeyleri 0,75 olarak belirlemiştir (Özçelik, 2010; Turgut ve Baykul, 2014). Her bir ilke için 0,75 düzeyine ulaşan öğrenciler başarılı kabul edilmiştir.

Üçüncü ve dördüncü alt problemlerin analizi için BYF ile 4. ve 5. sinıf öğrencilerinin sayı hissi durumlarını alınan eğitim türü ve sınıf düzeyi açısından karşılaştırmak için bağımsız gruplar t-testi yapılmıştır. Bağımsız gruplar ttestinde iki ayrı evren ya da iki ayrı davranış koşulları arasındaki ortalama farklar iki ayrı örneklemden toplanan veriler ile değerlendirilir (Gravetter ve Wallanu, 2013). 


\section{BULGULAR}

Çalışmanın bu kısmında araştırma sorularının sırasına göre bulgulara yer verilmiştir.

Araştırmanın birinci alt probleminde yer alan devlet okuluna devem eden dördüncü ve beşinci sınıf öğrencilerinin sayma ilkelerine ulaşma düzeylerini görmek için "Sayı Hissi Testi”" (SHT) uygulanmıştır. Öğrencilerin her bir soruya verdikleri cevaplara göre sayı hissi bileşenlerine ulaşma düzeyleri verilmiştir.

Tablo 1. Dördüncü Ve Beşinci Sınıf Öğrencilerinin Test Maddelerini Sayı Hissine Göre Ve Standart Kurallara Göre Cevaplama Yüzdeleri

\begin{tabular}{|c|c|c|c|c|}
\hline 营 & $\begin{array}{c}\text { 4.sınıf } \\
\text { standart } \\
\text { doğru yüzdesi }\end{array}$ & $\begin{array}{c}\text { 4.sınıf sayı } \\
\text { hissine göre } \\
\text { doğru yüzdesi }\end{array}$ & $\begin{array}{c}\text { 5.sinıf } \\
\text { standart } \\
\text { doğru yüzdesi }\end{array}$ & $\begin{array}{c}\text { 5.sınıf sayı } \\
\text { hissine göre } \\
\text { doğru yüzdesi }\end{array}$ \\
\hline
\end{tabular}

\begin{tabular}{ccccc}
\hline 1 & 28,3 & 0 & 26,2 & 0 \\
\hline 2 & 1,7 & 0 & 0 & 0 \\
\hline 3 & 3,3 & 3,3 & 8,2 & 8,2 \\
\hline 4 & 1,7 & 10,7 & 6,6 & 23 \\
\hline 5 & 36,7 & 6,7 & 44,3 & 0 \\
\hline 6 & 3,3 & 1,7 & 6,6 & 3,3 \\
\hline 7 & 18,3 & 0 & 29,5 & 4,9 \\
\hline 8 & 0 & 18,3 & 26,2 & 0 \\
\hline 9 & 3,3 & 55 & 6,6 & 47,5 \\
\hline 10 & 0 & 0 & 1,6 & 1,6 \\
\hline 11 & 50 & 0 & 59 & 1,6 \\
\hline 12 & 23,3 & 0 & 52,5 & 1,6 \\
\hline 13 & 10 & 0 & 44,3 & 0 \\
\hline 14 & 30 & 0 & 57,4 & 0 \\
\hline 15 & 1,7 & 0 & 21,3 & 0 \\
\hline 16 & 3,3 & 6,7 & 6,6 & 0 \\
\hline 17 & 16,7 & 18,3 & 4,9 & 1,6 \\
\hline
\end{tabular}

Tablo 1 incelendiğinde dördüncü ve beşinci sınıf öğrencilerinin "Sayı Hissi Testi" (SHT) sorularının hiçbirinde tam öğrenme düzeyi olarak kabul edilen 0.75 düzeyine ulaşılamadıkları görülmektedir. 5.sınıf öğrencilerinin 4. Sınıf öğrencilerine göre daha başarılı olduğu söylenebilir ancak devlet okuluna devam eden her iki sınıf seviyesinde de öğrencilerin sayı hissi bakımından oldukça zayıf oldukları görülmektedir. 
Aşağıda devlet okuluna gidip üstün yetenekli tanısı konmayan 4. ve 5.sinıf öğrencilerinin sayı hissi alt bileşenlerine göre SHT'den almış oldukları puan ortalamaları Tablo 2'de verilmiştir.

Tablo 2. Üstün Yetenekli Tanısı Konmayan Dördüncü Ve Beşinci Sınıf Öğrencilerinin Sayı Hissi Bileşenlerine Ulaşma Düzeyleri

\begin{tabular}{lcc}
\hline Sayı hissi bileşenleri & $\begin{array}{c}\text { 4.sınıf sayı hissi } \\
\text { bileşenlerine ulaşma } \\
\text { düzeyleri }\end{array}$ & $\begin{array}{c}\text { 5.sınıf sayı hissi } \\
\text { bileşenlerine ulaşma } \\
\text { düzeyleri }\end{array}$ \\
\hline $\begin{array}{l}\text { Sayının anlamını ve } \\
\text { büyüklüğ̈nü anlama }\end{array}$ & 12,3 & 32 \\
\hline $\begin{array}{l}\text { Sayının eş gösterimlerini } \\
\text { anlama ve kullanma }\end{array}$ & 27,9 & 37 \\
\hline $\begin{array}{l}\text { İşlemlerin anlamını ve } \\
\text { etkisini anlama }\end{array}$ & 14 & 23,5 \\
\hline $\begin{array}{l}\text { Eş ifadelerin kullanımı } \\
\text { ve anlamı }\end{array}$ & 29,15 & 28,6 \\
\hline $\begin{array}{l}\text { Zihinden işlem, yazılı } \\
\text { işlem ve hesap makinesi } \\
\text { kullanımı için sayma ve } \\
\text { esnek işlem stratejileri }\end{array}$ & 23 & 47,5 \\
\hline Ölçüm referansları & 27,5 & \\
\hline
\end{tabular}

Tablo 2'de görüldüğü gibi üstün yetenekli tanısı konmayan dördüncü ve beşinci sınıf öğrencilerinin sayı hissi bileşenlerinden hiçbirinde istenilen öğrenme düzeyi olan 0.75 'e ulaşamadıkları görülmektedir.

Aşağıdaki tablo 3'te ise BİLSEM'e devam eden üstün yetenekli dördüncü ve beşinci sınıf öğrencilerinin "Sayı Hissi Testi” (SHT) sorularına verdikleri doğru cevap yüzdeleri verilmiştir.

Tablo 3. Üstün Yetenekli Dördüncü Ve Beşinci Sınıf Öğrencilerinin Test Maddelerini Sayı Hissine Göre Ve Standart Kurallara Göre Cevaplama Yüzdeleri

\begin{tabular}{ccccc}
\hline & $\begin{array}{c}\text { 4.sınıf } \\
\text { standart } \\
\text { doğru yüzdesi }\end{array}$ & $\begin{array}{c}\text { 4.sinıf sayı } \\
\text { hissine göre } \\
\text { doğru yüzdesi }\end{array}$ & $\begin{array}{c}\text { 5.sınıf } \\
\text { standart } \\
\text { doğru yüzdesi }\end{array}$ & $\begin{array}{c}\text { 5.sınıf sayı } \\
\text { hissine göre } \\
\text { doğru yüzdesi }\end{array}$ \\
\hline 1 & 25 & 3,1 & 54,3 & 2,2 \\
\hline 2 & 14,6 & 3,1 & 26,1 & 10,9 \\
\hline
\end{tabular}




\begin{tabular}{ccccc}
\hline 3 & 68,8 & 0 & 84,8 & 0 \\
\hline 4 & 1,0 & 71,9 & 0 & 84,8 \\
\hline 5 & 58,3 & 0 & 60,9 & 0 \\
\hline 6 & 47,9 & 0 & 60,9 & 2,2 \\
\hline 7 & 25 & 44,8 & 30,4 & 54,3 \\
\hline 8 & 72,9 & 9,4 & 86,6 & 2,2 \\
\hline 9 & 2,1 & 91,7 & 0 & 97,8 \\
\hline 10 & 5,2 & 3,1 & 34,8 & 0 \\
\hline 11 & 62,5 & 17,7 & 34,8 & 54,3 \\
\hline 12 & 64,6 & 14,6 & 45,7 & 47,8 \\
\hline 13 & 69,8 & 2,1 & 80,4 & 0 \\
\hline 14 & 87,5 & 2,1 & 84,8 & 4,3 \\
\hline 15 & 57,3 & 1 & 69,6 & 6,5 \\
\hline 16 & 29,2 & 5,2 & 43,5 & 6,5 \\
\hline 17 & 15,6 & 12,5 & 4,3 & 10,9 \\
\hline
\end{tabular}

Tablo 3’te görüldüğü gibi BİLSEM'e devam eden dördüncü ve beşinci sınıf öğrencilerinin "Sayı Hissi Testi" (SHT) sorularına verdikleri cevaplara bakıldığında daha çok standart doğru cevaplar verdikleri görülmektedir. 4.sınıf standart doğru cevap ortalamas $\% 41,6 ; 4$.sınıf sayı hissine göre doğru cevap ortalamas $\% 16,6 ; 5$.sinıf standart doğru cevap ortalamas $\% 47,2$ ve 5 .sinıf sayı hissine göre doğru cevap ortalamas $1 \% 22,6$ 'dır. Bu ortalama puanlar tam öğrenme düzeyi olarak kabul edilen 0.75 düzeyinden oldukça uzak görülmektedir. BİLSEM öğrencileri arasında da 5.sınıf öğrencilerinin 4. Sınıf öğrencilerine göre daha başarılı olduğu söylenebilir.

Aşağıda Tablo 4'te BİLSEM'e devam eden üstün yetenekli 4. ve 5.sinıf öğrencilerinin sayı hissi alt bileşenlerine göre SHT'den almış oldukları puan ortalamaları verilmiştir.

Tablo 4. Özel Yetenekli Dördüncü Ve Beşinci Sınıf Öğrencilerinin Sayı Hissi Bileşenlerine Ulaşma Düzeyleri

\begin{tabular}{lcc}
\hline \multicolumn{1}{c}{ Sayı hissi bileşenleri } & $\begin{array}{c}\text { 4.sınıf sayı hissi } \\
\text { bileşenlerine ulaşma } \\
\text { düzeyleri }\end{array}$ & $\begin{array}{c}\text { 5.sınıf sayı hissi } \\
\text { bileşenlerine ulaşma } \\
\text { düzeyleri }\end{array}$ \\
\hline $\begin{array}{l}\text { Sayının anlamını ve } \\
\text { büyüklügünü anlama }\end{array}$ & 38,2 & 58,8 \\
\hline $\begin{array}{l}\text { Sayının eş gösterimlerini } \\
\text { anlama ve kullanma }\end{array}$ & 66 & 73 \\
$\begin{array}{l}\text { İşlemlerin anlamını ve } \\
\text { etkisini anlama }\end{array}$ & 67 & 79 \\
\hline
\end{tabular}




\begin{tabular}{|c|c|c|}
\hline $\begin{array}{l}\text { Eş ifadelerin kullanımı } \\
\text { ve anlamı }\end{array}$ & 51,5 & 66,3 \\
\hline $\begin{array}{l}\text { Zihinden işlem, yazılı } \\
\text { işlem ve hesap makinesi } \\
\text { kullanımı için sayma ve } \\
\text { esnek işlem stratejileri }\end{array}$ & 76 & 86 \\
\hline Ölçüm referanslar1 & 31,25 & 32,6 \\
\hline
\end{tabular}

Tablo 4'te görüldügü gibi üstün yetenekli tanıs1 konan dördüncü sinıf öğrencilerinin sayı hissi alt bileşenlerinden sadece "Zihinden işlem, yazılı işlem ve hesap makinesi kullanımı için sayma ve esnek işlem stratejileri” kategorisinde istenilen öğrenme düzeyi olan 0.75 'e ulaştıkları görülmüştür. Buna karşılık üstün yetenekli tanısı konan beşinci sınıf öğrencileri, sayı hissi bileşenlerinden "İşlemlerin anlamını ve etkisini anlama" ile "Zihinden işlem, yazılı işlem ve hesap makinesi kullanımı için sayma ve esnek işlem stratejileri" alt bileşenlerinde istenilen öğrenme düzeyine ulaştıkları görülmektedir. Ayrıca beşinci sınıf öğrencileri "Sayının eş gösterimlerini anlama ve kullanma" alt bileşeninde de \%73 ortalama ile hedef düzeye oldukça yaklaşmışlardır. Bu durumda üstün yetenekli tanıs1 konan ve BİLSEM'de eğitim almaya devam eden 5.sinıf öğrencilerinin sayı hissi alt bileşenleri bakımından en iyi puanı aldıkları söylenebilir.

Araştırmanın üçüncü alt probleminde "Devlet okuluna devam eden dördüncü ve beşinci sınıf öğrencilerinin sayı hissinin her bir alt bileşenlerine göre alınan puanlar arasında anlamlı fark var midır?" sorusuna SHT'ye verdikleri cevaplardan elde edilen puanlara göre t-testi yapılmış ve sonuçlar her bir alt bileşen için ayrı ayrı aşağıda verilmiştir.

Dördüncü ve beşinci sınıf öğrencilerinin "sayının anlamını ve büyüklüğünü anlama” bileşenine ilişkin SHT'ye verdikleri cevaplardan elde edilen puanlara göre t-testi sonuçları Tablo 5'te verilmiştir.

Tablo 5. Dördüncü Ve Beşinci Sınıf Öğrencilerinin “Sayının Anlamını Ve Büyüklügünü Anlama” Bileşenine İlişkin T-Testi Sonuçları

\begin{tabular}{lcccccc}
\hline Gruplar & $\mathrm{N}$ & $\mathrm{X}$ & $\mathrm{SS}$ & $\mathrm{Sd}$ & $\mathrm{t}$ & $\mathrm{p}$ \\
\hline 4.sinif & 60 &, 200 &, 259 & 120 &, 289 &, 773 \\
5.sinif & 62 &, 187 &, 245 & & & \\
\hline
\end{tabular}

Sayı hissinin sayının anlamı ve büyüklüğ̈̈nü anlama bileşeninde öğrencilerin toplam puanlarında dördüncü ve beşinci sınıfa giden öğrenciler arasında anlamlı bir fark görülmemiştir, $t(120)=, 289, p>0,05(p=0,773)$. Ancak dördüncü sinıf 
öğrencilerinin ortalama puanlarının beşinci sınıf öğrencilerinin ortalama puanlarından biraz daha yüksek olduğu söylenebilir.

Dördüncü ve beşinci sınıf öğrencilerinin "sayının eş gösterimini anlama ve kullanma" bileşenine ilişkin SHT'ye verdikleri cevaplardan elde edilen puanlara göre t-testi sonuçları Tablo 6'da verilmiştir.

Tablo 6. Dördüncü Ve Beşinci Sınıf Öğrencilerinin Sayının Eş Gösterimini Anlama Ve Kullanma Bileşenine İlişkin T-Testi Sonuçları

\begin{tabular}{lcccccc}
\hline Gruplar & $\mathrm{N}$ & $\mathrm{X}$ & $\mathrm{SS}$ & $\mathrm{Sd}$ & $\mathrm{t}$ & $\mathrm{p}$ \\
\hline 4.sinif & 60 &, 6750 &, 72967 & 120 & $-1,067$ &, 288 \\
5.sinif & 62 &, 8145 &, 71422 & & & \\
\hline
\end{tabular}

Tablo 6'da görüldüğü üzere sayı hissinin sayının eş gösterimini anlama ve kullanma bileşeninde öğrencilerin toplam puanlarında dördüncü ve beşinci sınıfa giden öğrenciler arasında anlamlı bir fark görülmemiştir, $t(120)=-1,067, p>0,05$ $(p=0,288)$. Ancak beşinci sinıfların puan ortalamasının dördüncü sınıf puan ortalamasından daha yüksek olduğu söylenebilir.

Dördüncü ve beşinci sınıf öğrencilerinin "işlemlerin anlamını ve etkisini anlama" bileşenine ilişkin SHT'ye verdikleri cevaplardan elde edilen puanlara göre t-testi sonuçları Tablo 7'de verilmiştir.

Tablo 7. Dördüncü Ve Beşinci Sınıf Öğrencilerinin İşlemlerin Anlamını Ve Etkisini Anlama Bileşenine İlişkin T-Testi Sonuçları

\begin{tabular}{lcccccc}
\hline Gruplar & $\mathrm{N}$ & $\mathrm{X}$ & $\mathrm{SS}$ & $\mathrm{Sd}$ & $\mathrm{t}$ & $\mathrm{p}$ \\
\hline 4.sinif & 60 &, 2056 &, 34221 & 120 &,- 826 &, 410 \\
5.sinif & 62 &, 2581 &, 35921 & & & \\
\hline
\end{tabular}

Tablo 7'de görüldüğü üzere sayı hissinin işlemlerin anlamını ve etkisini anlama bileşeninde öğrencilerin toplam puanlarında dördüncü ve beşinci sınıfa giden öğrenciler arasında anlamlı bir fark görülmemiștir, $t(120)=-, 826, p>0,05$ $(p=0,410)$. Beşinci sınıf puan ortalamasının dördüncü sınıf puan ortalamasından daha yüksek olduğu söylenebilir.

Dördüncü ve beşinci sınıf öğrencilerinin "eş ifadelerin kullanımı ve anlamı" bileşenine ilişkin SHT'ye verdikleri cevaplardan elde edilen puanlara göre t-testi sonuçları Tablo 8'de verilmiştir. 
Tablo 8. Dördüncü Ve Beşinci Sınıf Öğrencilerinin Eş İfadelerin Kullanımı Ve Anlamı Bileşenine İlişkin T-Testi Sonuçları

\begin{tabular}{lcccccc}
\hline Gruplar & $\mathrm{N}$ & $\mathrm{X}$ & $\mathrm{SS}$ & $\mathrm{Sd}$ & $\mathrm{t}$ & $\mathrm{p}$ \\
\hline 4.sinif & 60 &, 6333 &, 44021 & 120 &,- 229 &, 820 \\
5.sinif & 62 &, 6532 &, 51684 & & & \\
\hline
\end{tabular}

Tablo 8'de görüldüğü üzere sayı hissinin eş ifadelerin kullanımı ve anlamı bileşeninde öğrencilerin toplam puanlarında dördüncü sınıfa giden ve beşinci sınıfa giden öğrenciler arasında anlamlı bir fark görülmemiştir, $t(120)=-, 229$, $p>0,05(p=0,820)$. Beşinci sınıf puan ortalamasının dördüncü sınıf puan ortalamasından daha yüksek olduğu görülmektedir.

Dördüncü ve beşinci sınıf öğrencilerinin "zihinden işlem, yazılı işlem ve hesap makinesi kullanımı için sayma ve esnek işlem stratejileri” bileşenine ilişkin SHT'ye verdikleri cevaplardan elde edilen puanlara göre t-testi sonuçları Tablo 9'da verilmiştir.

Tablo 9. Dördüncü Ve Beşinci Sınıf Öğrencilerinin Zihinden İşlem, Yazılı İşlem Ve Hesap Makinesi Kullanımı İçin Sayma Ve Esnek İşlem Stratejileri Bileşenine İlişkin T-Testi Sonuçları

\begin{tabular}{lcccccc}
\hline Gruplar & $\mathrm{N}$ & $\mathrm{X}$ & $\mathrm{SS}$ & $\mathrm{Sd}$ & $\mathrm{t}$ & $\mathrm{p}$ \\
\hline 4.sinif & 60 &, 2400 &, 23807 & 120 & $-4,625$ &, 000 \\
5.sinif & 62 &, 5000 &, 37064 & & & \\
\hline
\end{tabular}

Tablo 9'da görüldüğü üzere sayı hissinin zihinden işlem, yazılı işlem ve hesap makinesi kullanımı için sayma ve esnek işlem stratejileri bileşeninde öğrencilerin toplam puanlarında dördüncü ve beşinci sınıfa giden öğrenciler arasında beşinci sinıf öğrencilerinin lehine anlamlı fark görülmüştür, $t(120)=-4,625, p<0,05$ $(p=0,000)$.

Dördüncü ve beşinci sınıf öğrencilerinin "Ölçüm referansları" bileşenine ilişkin SHT'ye verdikleri cevaplardan elde edilen puanlara göre t-testi sonuçları Tablo 10'da verilmiştir.

Tablo 10. Dördüncü Ve Beşinci Sınıf Öğrencilerinin Ölçüm Referansları Bileşenine İlişkin T-Testi Sonuçları

\begin{tabular}{lcccccc}
\hline Gruplar & $\mathrm{N}$ & $\mathrm{X}$ & $\mathrm{SS}$ & $\mathrm{Sd}$ & $\mathrm{t}$ & $\mathrm{p}$ \\
\hline 4.sinif & 60 &, 5167 &, 58198 & 120 & 4,113 &, 000 \\
5.sinif & 62 &, 1613 &, 33601 & & & \\
\hline
\end{tabular}


Tablo 10'da görüldüğü üzere sayı hissinin ölçüm referansları bileşeninde öğrencilerin toplam puanlarında dördüncü ve beşinci sınıfa giden öğrenciler arasında dördüncü sınıf öğrencilerinin lehine anlamlı fark görülmüştür, $t(120)=$ 4,113, $p<0,05(p=0,000)$.

Devlet okuluna devam eden dördüncü ve beşinci sınıf öğrencilerinin sayı hissinin alt bileşenlerine göre alınan puanlar arasında üç bileşende sınıflar arasında anlamlı fark çıkmıştır. Bunlardan ikisi beşinci sınıf lehine biri de dördüncü sınıf lehine çıkmıştır.

Araştırmanın dördüncü alt probleminde "BILLSEM'e devam eden BYF dönemi öğrencilerinin sayı hissinin her bir alt bileşenlerine göre alınan puanlar arasında anlamlı fark var midır?" sorusuna SHT'ye verdikleri cevaplardan elde edilen puanlara göre t-testi yapılmış ve sonuçlar her bir alt bileşen için ayrı ayrı aşağıda verilmiştir.

BİLSEM'e devam eden BYF dönemi öğrencilerinin sayı hissi genel ortalama puanlarına ilişkin SHT'ye verdikleri cevaplardan elde edilen puanlara göre t-testi sonuçları Tablo 11'de verilmiştir.

Tablo 11. Bilsem'e Devam Eden Byf Öğrencilerinin Sayı Hissi Genel Ortalama Puanlarına İlişsin T-Testi Sonuçları

\begin{tabular}{lcccccc}
\hline Gruplar & N & X & SS & Sd & t & p \\
\hline 4.sinif & 96 & 1,022 &, 24 & 180 & 4,990 &, 000 \\
5.sinif & 86 & 1,244 &, 25 & & & \\
\hline
\end{tabular}

Tablo 11'de görüldüğü gibi BİLSEM'de BYF dönemi öğrencilerinden dördüncü sınıfa devam eden öğrencilerin sayı hissi başarı ortalaması 1,022 ve bu gruba ait standart sapma 0,24'tür BİLSEM'de BYF dönemi öğrencilerinden beşinci sınıfa devam eden öğrencilerin sayı hissi başarı ortalaması 1,244 ve bu gruba ait standart sapma 0,25 'tir. BİLSEM'de BYF dönemi beşinci sınıfa devam eden öğrencilerin genel sayı hissi başarı ortalaması, BİLSEM'de BYF dönemi dördüncü sınıfa devam eden öğrencilerin başarı ortalamasından anlamlı düzeyde yüksektir, $\mathrm{t}(180)=4,990, \mathrm{p}<0,05(\mathrm{p}=0,00)$. BİLSEM beşinci sınıfa devam eden öğrencilerin sayı hissi başarılarının daha yüksek olduğu söylenebilir.

BİLSEM'e devam eden BYF dönemi öğrencilerinin sayı hissinin "sayının anlamını ve büyüklüğünü anlama” bileşenine ilişkin SHT’ye verdikleri cevaplardan elde edilen puanlara göre t-testi sonuçları Tablo 12'de verilmiştir. 
Tablo 12. BİLSEM'e Devam Eden Byf Dönemi Öğrencilerinin Sayının Anlamını Ve Büyüklügünü Anlama Bileşenine İlişkin T-Testi Sonuçları

\begin{tabular}{lcccccc}
\hline Gruplar & N & X & SS & Sd & t & p \\
\hline 4.sinıf & 96 &, 642 &, 402 & 180 & 2,310 &, 022 \\
5.sinıf & 86 &, 826 &, 519 & & & \\
\hline
\end{tabular}

Tablo 12'de görüldüğü gibi BİLSEM'de BYF dönemi öğrencilerinden dördüncü sınıfa devam eden öğrencilerin sayı hissinin sayının anlamını ve büyüklügünü anlama bileșeninde başarı ortalaması 0,642 ve bu gruba ait standart sapma 0,402'dir. BİLSEM'de BYF dönemi öğrencilerinden beşinci sınıfa devam edenlerin sayı hissinin sayının anlamını ve büyüklüğünü anlama bileșeninde başarı ortalamas1 0,826 ve bu gruba ait standart sapma 0,519'dur. BİLSEM'de beşinci sınıfa devam eden öğrencilerin sayı hissinin sayı hissinde sayının anlamını ve büyüklüğünü anlama bileşeninde başarı ortalaması BİLSEM'de dördüncü sınıfa devam eden öğrencilerin başarı ortalamasından anlamlı düzeyde yüksektir, $\mathrm{t}(180)=2,310, \mathrm{p}<0,05 \quad(\mathrm{p}=0,022)$. Beşinci sinıf BİLSEM öğrencilerinin sayı hissinin sayının anlamını ve büyüklüğ̈̈nü anlama bileşeninde daha başarılı olduğu söylenebilir.

BİLSEM'e devam eden BYF dönemi öğrencilerinin sayı hissinin "sayının eş gösterimini anlama ve kullanma" bileşenine ilişkin SHT'ye verdikleri cevaplardan elde edilen puanlara göre t-testi sonuçları Tablo 13'te verilmiştir.

Tablo 13. BİLSEM'e Devam Eden Byf Dönemi Öğrencilerinin Sayının Eş Gösterimini Anlama Ve Kullanma Bileşenine İlişkin T-Testi Sonuçları

\begin{tabular}{lcccccc}
\hline Gruplar & N & X & SS & Sd & t & p \\
\hline 4.sinif & 96 & 1,609 &, 459 & 180 &,- 802 &, 424 \\
5.sinif & 86 & 1,673 &, 424 & & & \\
\hline
\end{tabular}

Tablo 13'te BİLSEM'de BYF dönemi öğrencilerinden beşinci sınıfa devam edenlerin sayı hissinin sayının eş gösterimini anlama ve kullanma bileşeninde başarı ortalaması BİLSEM'de dördüncü sınıfa devam eden öğrencilerin başarı ortalamaları arasında anlamlı fark görülmemiştir, $\mathrm{t}(180)=-, 802, \mathrm{p}>0,05$ $(\mathrm{p}=0,424)$.

BİLSEM'e devam eden BYF dönemi öğrencilerinin sayı hissinin "işlemlerin anlamını ve etkisini anlama" bileşenine ilişkin SHT'ye verdikleri cevaplardan elde edilen puanlara göre t-testi sonuçları Tablo 14'te verilmiştir. 
Tablo 14. BILLSEM'e Devam Eden Byf Dönemi Öğrencilerinin İşlemlerin Anlamını Ve Etkisini Anlama Bileşenine İlişkin T-Testi Sonuçları

\begin{tabular}{lcccccc}
\hline Gruplar & $\mathrm{N}$ & $\mathrm{X}$ & $\mathrm{SS}$ & $\mathrm{Sd}$ & $\mathrm{t}$ & $\mathrm{p}$ \\
\hline 4.sinif & 96 & 1,05 &, 535 & 180 & 2,453 &, 015 \\
5.sinıf & 86 & 1,29 &, 576 & & & \\
\hline
\end{tabular}

Tablo 14'te görüldüğü gibi BILLSEM'de BYF dönemi dördüncü sınıfa devam eden öğrencilerin sayı hissinin işlemlerin anlamını ve etkisini anlama bileşeninde başarı ortalaması 1,05 ve bu gruba ait standart sapma $0,535^{\prime}$ 'tir. BILSEM'de BYF dönemi beşinci sınıfa devam eden öğrencilerin sayı hissinin işlemlerin anlamını ve etkisini anlama bileşeninde başarı ortalaması 1,29 ve bu gruba ait standart sapma 0,576'dır. BİLSEM'de beşinci sınıfa devam eden öğrencilerin sayı hissinin işlemlerin anlamını ve etkisini anlama bileşeninde başarı ortalaması BİLSEM'de dördüncü sınıfa devam eden öğrencilerin başarı ortalamasından anlamlı düzeyde yüksektir, $\mathrm{t}(180)=2,453, \mathrm{p}<0,05(\mathrm{p}=0,015)$. Beşinci sınıf öğrencilerinin sayı hissinin işlemlerin anlamını ve etkisini anlama bileşeninde daha başarılı olduğu söylenebilir.

BİLSEM'e devam eden BYF dönemi öğrencilerinin sayı hissinin "eş ifadelerin kullanımı ve anlamı" bileşenine ilişskin SHT'ye verdikleri cevaplardan elde edilen puanlara göre t-testi sonuçları Tablo 15'te verilmiştir.

Tablo 15. BILLSEM'e Devam Eden Byf Dönemi Öğrencilerinin Eş İfadelerin Kullanımı Ve Anlamı Bileşenine İlişkin T-Testi Sonuçları

\begin{tabular}{lcccccc}
\hline Gruplar & $\mathrm{N}$ & $\mathrm{X}$ & $\mathrm{SS}$ & $\mathrm{Sd}$ & $\mathrm{t}$ & $\mathrm{p}$ \\
\hline 4.sinif & 96 & 1,458 &, 462 & 180 & 2,383 &, 019 \\
5.sinıf & 86 & 1,641 &, 344 & & & \\
\hline
\end{tabular}

Tablo 15'te görüldüğü gibi BİLSEM'de BYF dönemi dördüncü sınıfa devam eden öğrencilerin sayı hissinin eş ifadelerin kullanımı ve anlamı bileşeninde başarı ortalaması 1,458 ve bu gruba ait standart sapma 0,462'dir. BİLSEM'de BYF dönemi beşinci sınıfa devam eden öğrencilerin sayı hissinin eş ifadelerin kullanımı ve anlamı bileşeninde başarı ortalaması 1,641 ve bu gruba ait standart sapma 0,344'tür. BİLSEM'de beşinci sınıfa devam eden öğrencilerin sayı hissinin eş ifadelerin kullanımı ve anlamı bileşeninde başarı ortalaması dördüncü sınıfa devam eden öğrencilerin başarı ortalamasından anlamlı düzeyde yüksektir, $\mathrm{t}(180)=2,383, \mathrm{p}<0,05(\mathrm{p}=0,019)$. Beşinci sınıf öğrencilerinin sayı eş ifadelerin kullanımı ve anlamı bileşeninde daha başarılı olduğu söylenebilir. 
BILLSEM'e devam eden BYF dönemi öğrencilerinin sayı hissinin "işlemlerin anlamını ve etkisini anlama" bileşenine ilişkin SHT'ye verdikleri cevaplardan elde edilen puanlara göre t-testi sonuçları Tablo 16'da verilmiştir.

Tablo 16. BİLSEM'e Devam Eden Byf Dönemi Öğrencilerinin İşlemlerin Anlamını Ve Etkisini Anlama Bileşenine İlişkin T-Testi Sonuçları

\begin{tabular}{lcccccc}
\hline Gruplar & N & X & SS & Sd & t & p \\
\hline 4.sinif & 96 &, 935 &, 474 & 180 & 3,931 &, 000 \\
5.sinif & 86 & 1,317 &, 571 & & & \\
\hline
\end{tabular}

Tablo 16'da görüldüğü gibi BİLSEM'de BYF dönemi dördüncü sınıfa devam eden öğrencilerin sayı hissinin işlemlerin anlamını ve etkisini anlama bileşeninde başarı ortalaması 0,935 ve bu gruba ait standart sapma 0,474'tür. BİLSEM'de BYF dönemi beşinci sınıfa devam eden öğrencilerin sayı hissinin işlemlerin anlamını ve etkisini anlama bileşeninde başarı ortalaması 1,317 ve bu gruba ait standart sapma 0,571'dir. BİLSEM'de beşinci sınıfa devam eden öğrencilerin sayı hissinin işlemlerin anlamını ve etkisini anlama bileşeninde başarı ortalaması BİLSEM'de dördüncü sınıfa devam eden öğrencilerin başarı ortalamasından anlamlı düzeyde yüksektir, $\mathrm{t}(180)=3,931, \mathrm{p}<0,05(\mathrm{p}=0,000)$. Beşinci sınıf öğrencilerinin işlemlerin anlamını ve etkisini anlama bileşeninde daha başarılı olduğu söylenebilir.

BİLSEM'e devam eden BYF dönemi öğrencilerinin sayı hissinin "ölçüm referansları" bileşenine ilişkin SHT'ye verdikleri cevaplardan elde edilen puanlara göre t-testi sonuçları Tablo 17'de verilmiştir.

Tablo 17. BİLSEM'e Devam Eden Byf Dönemi Öğrencilerinin Ölçüm Referansları Bileşenine İlişkin T-Testi Sonuçları

\begin{tabular}{lcccccc}
\hline Gruplar & $\mathrm{N}$ & $\mathrm{X}$ & $\mathrm{SS}$ & $\mathrm{Sd}$ & $\mathrm{t}$ & $\mathrm{p}$ \\
\hline 4.sinif & 96 &, 739 &, 725 & 180 &, 322 &, 748 \\
5.sinif & 86 &, 782 &, 786 & & & \\
\hline
\end{tabular}

Tablo 17'de görüldüğü gibi BİLSEM'de BYF dönemi beşinci sınıfa devam eden öğrencilerin sayı hissinin ölçüm referansları bileşeninde başarı ortalaması BİLSEM'de BYF dönemi dördüncü sınıfa devam eden öğrencilerin başarı ortalamaları arasında anlamlı fark görülmemiştir, $\mathrm{t}(180)=, 322, \mathrm{p}>0,05$ $(\mathrm{p}=0,748)$.

BİLSEM'e devam eden dördüncü ve beşinci sınıf öğrencilerinin sayı hissinin alt bileşenlerine göre alınan puanlar arasında dört bileşende sınıflar arasında 
5.sınıf lehine anlamlı fark çıkmıştır. Anlamlı fark çıkan sayı hissi alt bileşenleri, sayının anlamını ve büyüklüğünü anlama; işlemlerin anlamını ve etkisini anlama; eş ifadelerin kullanımı ve anlamı; işlemlerin anlamını ve etkisini anlamadır. Bu çıkan farkların tamamı beşinci sınıf lehine olmuştur. Genel olarak da BILLSEM'de beşinci sınıfa devam eden öğrencilerin sayı hissi başarı ortalaması dördüncü sınıfa devam eden öğrencilerin sayı hissi başarı ortalamasından anlamlı düzeyde yüksek çıkmıştır.

\section{TARTIŞMA VE SONUÇLAR}

Bu çalışma hem devlet okulunda öğrenim gören hem de BİLSEM'de eğitim alan öğrencilerin sayı hissi konusunda başarılı olduğu ve güçlük yaşadıkları alt bileşenlerinin belirlenmesine yönelik dördüncü ve beşinci sınıf öğrencilerinin sayı hissi düzeylerinin karşılaştırılması amacıyla yapılmıştır. Dördüncü ve beşinci sınıf öğrencilerinin sayma ilkelerine ulaşma düzeylerini belirlemek için "Sayı Hissi Testi" (SHT) uygulanmış ve öğrencilerin her bir soruya verdikleri cevaplara göre sayı hissi bileşenlerine ulaşma düzeyleri bulunmuştur. Buna göre sayı hissi bakımından üstün yetenekli tanısı konmayan dördüncü ve beşinci sınıf öğrencilerinin tam öğrenme düzeyi olarak kabul edilen 0.75 düzeyine ulaşılamadıkları sonucu çıkmıştır. Ancak yine de 5.sınıf öğrencilerinin 4. Sınıf öğrencilerine göre daha yüksek puan aldıkları görülmüştür. Bunun nedeni 5.sınıf öğrencilerinin sayı hissinin alt bileşenlerine yönelik olarak sorulan soruları bir üst sınıfta olmanın avantajı ile daha fazla doğru cevap vermeleri olabilir. Devlet okuluna devam eden ve üstün yetenekli tanısı konmayan dördüncü ve beşinci sınıf öğrencilerinin sayı hissinin alt bileşenlerine göre alınan puanlar arasında üç bileşende sınıflar arasında anlamlı fark çıkmıştır. Bunlardan ikisi beşinci sınıf lehine biri de dördüncü sınıf lehinedir. Devlet okuluna devam eden ve üstün yetenekli tanısı konmayan öğrencilerin her iki sınıf seviyesinde de sayı hissi bakımından oldukça zayıf oldukları görülmüştür. Bunun nedeni de öğretim programlarında sayı hissi ve alt bileşenlerine yönelik bir kazanımın bulunmaması olabilir.

BİLSEM'e devam eden BYF dönemi dördüncü ve beşinci sınıf öğrencilerinin SHT'ye verdikleri cevaplara bakıldığında daha çok standart doğru cevaplar verdikleri görülmüştür. 4.sınıf öğrencilerin sayı hissi bakımından 5.sınıf öğrencilerine oranla çok daha geride oldukları elde edilen puanlarla ortaya konulmuştur. Üstün yetenekli tanısı konan dördüncü sınıf öğrencilerinin sayı hissi alt bileşenlerinden sadece "Zihinden işlem, yazılı işlem ve hesap makinesi kullanımı için sayma ve esnek işlem stratejileri” kategorisinde istenilen öğrenme düzeyine ulaştıkları görülmüştür. Buna karşılık üstün yetenekli tanısı konan beşinci sınıf öğrencileri, sayı hissi bileşenlerinden "İşlemlerin anlamını ve etkisini anlama" ile "Zihinden işlem, yazılı işlem ve hesap makinesi kullanımı için sayma ve esnek işlem stratejileri" alt bileşenlerinde istenilen öğrenme 
düzeyine ulaştıkları ve "Sayının eş gösterimlerini anlama ve kullanma" alt bileşeninde ise bu düzeyine oldukça yaklaşmışlardır. BİLSEM'e devam eden beşinci sınıf öğrencilerin de sayı hissi başarılarının daha yüksek olduğu görülmüştür.

Dördüncü ve beşinci sınıf öğrencilerinin sayı hissi becerileri karşılaştırıldığında sayının anlamını ve büyüklüğünü anlama, sayının eş gösterimlerini anlama ve kullanma, işlemlerin anlamını ve etkisini anlama, eş ifadelerin kullanımı ve anlamı bileşenlerinde dördüncü ve beşinci sınıflar arasında anlamlı fark görülmezken, ölçüm referansları bileşeninde dördüncü sınıf öğrencilerinin lehine, zihinden işlem, yazılı işlem ve hesap makinesi kullanımı için sayma ve esnek işlem stratejileri bileşeninde ise beşinci sınıf öğrencilerinin lehine anlamlı fark saptanmıştır. Bu çalışma ile yurt içinde yapılan çalışmalar (Altay, 2011; İymen ve Paksu, 2015; Dede, 2015; Kartal, 2016) öğrencilerin say1 hissi becerilerinin düşük olması açısından benzerlik göstermektedir. Benzer şekilde Yang (2007) ve Yang, Reys ve Reys (2009) çalışmalarında öğretmen adaylarının da sayı hissi algılarının düşük olduğu sonucuna ulaşmıştır.

$\mathrm{Bu}$ araştırmada öğrencilerin rutin işleme ve sayı hissine yönelik toplam cevapları incelendiğinde sayı hissi becerisinin düşük olması genel matematik başarısının düşük olması ile ilişkilendirilebilir. Çalışma bu yönüyle Çekirdekçi, Şengül ve Doğan'ın (2016) çalışmasında sayı hissi ile matematik başarısı arasındaki pozitif ilişki sonucu ile benzerlik göstermektedir. Yine Can (2019), öğrencilerin sayı duyusu kullanımının düşük olduğunu fakat soruların görselle desteklenmesi; karşılaştırma, tahmin, referans alma gibi durumlar içermesi; soru kökünde algoritma kullanmadan çözmeye yönelik küçük ipuçlarının yer alması; kullanılan sayıların yuvarlama, parçalama/birleştirme gibi durumlara uygun olmasının öğrencilerin sayı hissi kullanımını arttırdığını ifade etmiş̧ir. Bu özelliklerdeki sorularla BİLSEM öğrencilerinin bu kurumlarda aldıkları eğitim çeşitliliğinden dolayı devlet okullarına devam eden akranlarından daha çok karşılaştığından dolayı üstün yetenekli öğrencilerin sayı hissinin daha fazla geliştiği söylenebilir.

Altay (2010) altı, yedi ve sekizinci sınıf öğrencilerinin sayı hissi durumlarına baktığında altıncı sınıf öğrencilerinin en yüksek sayı hissine sahip olduğu bulgusu bu çalışmada sayı hissinin bileşeni olan ölçüm referansı bileşeninin dördüncü sınıf öğrencilerinin lehine olması ile benzerlik; Sayının anlamını ve büyüklügünü anlama, Sayının eş gösterimlerini anlama ve kullanma, İşlemlerin anlamını ve etkisini anlama, Eş ifadelerin kullanımı ve anlamı, zihinden işlem bileşenlerinin her birinde dört ve beşinci sınıflar için anlamlı bir fark görülmemesi ve yazılı işlem ve hesap makinesi kullanımı için sayma ve esnek işlem stratejileri bileşeninde beşinci sınıf lehine anlamlı fark göstermesi yapılan çalışma ile farklılık göstermektedir. Başka bir çalışmada Mutlu, Olkun ve Cumhur (2019)'un 
dokunsay sayı tabletlerinin okul öncesi 48-60 ay dönemi çocuklarının aritmetik becerilerinin gelişimi üzerindeki etkisini araştırdıkları çalışmada sayı hissinin ilk basamağı olan "sayının anlamının ve büyüklügünü anlama"da olumlu yönde etki ettiği görülmüştür. $\mathrm{Bu}$ sonuç da öğrencilerin erken yaşta sayı hissi ile tanışmalarının onların ileriki matematik öğrenme düzeylerine etki edeceğini gösterebilir.

BİLSEM'e devam eden BYF dönemi öğrencilerinin üstün yetenekli tanıs1 konmayan devlet okulunda devam eden akranlarına göre sayı hissi genel puanları bakımından anlamlı düzeyde daha ileride oldukları görülmektedir. Buna göre BİLSEM'de uygulanan etkinlik temelli zenginleştirilmiş ve derinlemesine verilen eğitimin çocukların sayı hissine olumlu katkılar sunduğu sonucunu ortaya çıkarmaktadır. Üstün yetenekli tanısı konmayan devlet okulunda devam eden öğrenciler için de etkinlik temelli öğretim uygulamalarına ağılık verilmesi önerilebilir.

Sayı hissi kavramı öğrencilerin sayısal içerikli problemlerde çözüme ulaşmak için sayıları esnek ve akıcı bir şekilde kullanılmaları için oldukça önemlidir. Özellikle tahmin etme ve zihinden yaklaşık hesap yapma gerektiren fermi problemlerini çözme becerilerinin gelişmesinde oldukça önemlidir. İlkokul ve ortaokul matematik öğretim programlarında sayı hissi ve alt bileşenlerinin öğretimine yönelik kazanımların bulunmasını matematik başarısını arttıracağı düşüncesiyle tavsiye edilebilir.

\section{KAYNAKÇA}

Altay, Mesture Kayhan (2010), An investigation of middle grade students number sense in terms of grade level, gender and components of number sense. Doctoral thesis, Hacettepe University, Social Sciences Institute, Ankara, Turkey.

Armería-Zavala, Luis ve Hernández-Gallardo, Sara Catalina (2012), "Development of number sense in third grade of elementary school using serious game". In Proceedings of the 20th International Conference on Computers in Education. Singapore: Asia-Pacific Society for Computers in Education, ss. 26-30.

Can, Derya (2019), “İlkokul dördüncü sınıf öğrencilerinin sayı duyusu performansının bazı değişkenler açısından incelenmesi”. Elementary Education Online, 18(4), ss.1751-1765.

Clinkenbeard, Pamela R. (2007), "Economic arguments for gifted education”. Gifted Children, 2(1), ss. 5-9. Retrieved from http://docs.lib.purdue.edu/ giftedchildren/vol2/iss1/3 
Çekirdekçi, Sıtkı; Şengül, Sare ve Doğan, M. Cihangir (2016), “4. Sınıf öğrencilerinin sayı hissi ile matematik başarıları arasındaki ilişkinin incelenmesi. [Examining the relationship between number sense and mathematics achievement of the 4th grade students]". Qualitative Studies, 11(4), ss. 48-66.

Dunphy, Elizabeth (2007), “The primary mathematics curriculum: Enhancing its potential for developing young children's number sense in the early years at school”. Irish Educational Studies, 26(1), ss. 5-25. Retrieved from https://www.tandfonline.com/doi/full/10.1080/03323310 $\underline{601125088}$

Etuk, Emmanuel Dan ve Bello Daniel Oluyinka (2016), “Challenges and prospects of mathematics education in Nigeria". Journal of Assertiveness, ss. 1-8. Retrieved from http://www.global academicgroup.com/journals/assertiveness/Emmanuel\%20Dan.pdf

Florida, Richard (2005), Cities and the creative class. New York: Routledge.

Greeno, James G. (1991), "Number sense as situated knowing in a conceptual domain”. Journal of Research in Mathematics Education, 22(3), ss. 170218.

Gülbağcı-Dede, Hande ve Şengül Sare (2016), “İlköğretim ve Ortaöğretim Matematik Öğretmen Adaylarının Sayı Hissinin İncelenmesi”. Turkish Journal of Computer and Mathematics Education, 7(2), ss. 285-303.

İymen, Esra ve Duatepe-Paksu, Asuman (2015), "8. sınıf öğrencilerinin üslü ifadeler ile ilgili sayı duyularının sayı duyusu bileşenleri bakımından incelenmesi”. Eğitim ve Bilim, 40(177), ss. 109-125. Doi:10.15390/EB.2015.2710

Jordan, Nancy; Kaplan, David; Locuniak, Maria N. ve Chaitanya Ramineni (2007), "Predicting first-grade math achievement from developmental number sense trajectories”. Learning Disabilities Research \& Practice, 22(1), ss. 36-46.

Kartal, Aygül (2016), 8. Sınıf Öğrencilerinin Kesirlerde Sayı Duyularının İncelenmesi. Yayımlanmamış Doktora Tezi, Recep Tayyip Erdoğan Üniversitesi, Sosyal Bilimler Enstitüsü, Rize.

Kayhan-Altay, Mesture (2010), İlköğretim ikinci kademe öğrencilerinin sayı duyularının; sınıf düzeyine, cinsiyete ve sayı duyusu bileşenlerine göre 
incelenmesi. Yayınlanmamış Doktora Tezi, Hacettepe Üniversitesi, Sosyal Bilimler Enstitüsü, Ankara.

Kayhan-Altay, Mesture ve Umay, Aysun (2011), “Sınıf öğretmeni adaylarının hesaplama becerileri ve sayı duyuları arasındaki ilişkinin incelenmesi”. E-Journal of New World Sciences Academy, 6(1), ss. 12771283.

Markovits, Zvia ve Sowder, Judith (1994), "Developing number sense: An intervention study in grade 7". Journal for Research in Mathematics Education, 25(1), ss. 4-29. https://doi.org/10.2307/749290

McIntosh, Alistair; Reys, Barbara J. ve Reys, Robert E. (1992), “A proposed framework for examining basic number sense". For the Learning of Mathematics, 12(3), ss. 2-8. Retrieved from https://flm-journal.org/ Articles/94F594EF72C03412F1760031075F2.pdf

MEB (2018), Matematik Dersi Öğretim Programı (İlkokul ve Ortaokul 1-8. Sınıflar). Milli Eğitim Bakanlığı, Ankara.

MEB (2016), Bilim ve Sanat Merkezi Yönergesi. Milli Eğitim Bakanlığı, Ankara.

Mutlu, Yılmaz; Olkun, Sinan ve Cumhur, Fatma (2019), "Dokunsay sayı tabletlerinin okul öncesi çocuklarının aritmetik becerileri üzerindeki etkisinin incelenmesi”. Elementary Education Online, 18(1), ss. 437-450. Doi: 10.17051/ilkonline.2019.527655

NCTM (2000), Principles and standards for school mathematics. Reston, VA: NCTM.

Nobbe, Christine ve Davis, Kristin (2019), Recommendations for Providing Levels of Services for Gifted and Advanced Students. Missouri Department of Elementary and Secondary Education, Missouri.

Oliveira, Maria Fatima - Negreiros, João Garrott Marques ve Neves, Ana Cristina (2015), "Constraints of learning mathematics: A systemic historical review of the literature". Education Pesqui, 41(4), ss. 1023-1037. http://dx.doi.org/10.1590/s1517-97022015051533

Olkun, Sinan; Altun, Arif; Sahin, Sakine Göçer ve Denizli, Zeynep Akkurt (2015), "Deficits in basic number competencies may cause low numeracy in primary school children”. Egitim ve Bilim, 40(177), ss. 141-159. 
Olkun, Sinan ve Toluk-Uçar, Zülbiye (2009), İlköğretimde etkinlik temelli matematik öğretimi. Ankara: Eğiten Kitap.

Renzulli, Joseph (1986), "The three- ring conception of giftednes: A development model for Creative productivity”. In: Sterberg, Robert and Dabidson, Janet (Orgs.). Conceptions of giftedness. New York: Cambridge University Press, ss. 53-92.

Reys, Robert; Reys, Barbara; Emanuelsson, Goran; Johansson, Bengt; McIntosh, Alistair ve Yang, Der Ching (1999), “Assessing number sense of students in Australia, Sweden, Taiwan, and the United States”. School Science and Mathematics, 99(2), ss. 61-70. Doi:10.1111/j.19498594.1999.tb17449.x

Rindermann, Heiner; Sailer, Michael ve Thompson, James (2009), “The impact of smart fractions, cognitive ability of politicians and average competence of peoples on social development". Talent Development and Excellence, 1, ss. 3-25.

Sowder, Judith ve Schappelle, Bonnie (1994). "Number sense-making". Arithmetic Teacher, 41(6), ss. 342-346.

Şengül, Sare ve Gülbağc1-Dede, Hande (2014), "Matematik Öğretmenlerinin Sayı Hissi Problemlerini Çözerken Kullandıkları Stratejiler”. Turkish Journal of Computer and Mathematics Education (TURCOMAT),5 (1), ss. 73-88. Retrieved from https://dergipark.org.tr/tr/pub/turkbilmat/issue /21572/231496

Van de Walle, John A.; Karp, Karen S. ve Bay-Williams, Jennifer M. (2012), İlkokul ve ortaokul matematiği gelişimsel yaklaşımla öğretim. (Editör: Soner Durmuş). Ankara: Nobel.

Yang, Der-Ching - Li, Mao-neng ve Lin, Chih-I (2008), “A study of the performance of $5^{\text {th }}$ graders in number sense and its relationship to achievement in mathematics". International Journal of Science and Mathematics Education, 6, ss. 789-807. Doi: 10.1007/Student 10763-0079100-0

Yang, Der-Ching ve Li, Mao-neng (2013), “Assessment of animated selfdirected learning activities modules for children's number sense development”. Journal of Educational Technology \& Society, 16(3), ss. 44-58. Retrieved from https://www.jstor.org/stable/pdf/jeductechsoci. 16.3.44.pdf 